\title{
Anaerobic oxidation of methane above gas hydrates at Hydrate Ridge, NE Pacific Ocean
}

\author{
Tina Treude ${ }^{1, *}$, Antje Boetius ${ }^{1,2,3}{ }^{,}$Katrin Knittel $^{1}{ }$ Klaus Wallmann $^{4}$, \\ Bo Barker Jørgensen ${ }^{1}$
}

\footnotetext{
${ }^{1}$ Max Planck Institute for Marine Microbiology, Department of Biogeochemistry, Celsiusstrasse 1, 28359 Bremen, Germany

${ }^{2}$ Alfred Wegener Institute for Polar and Marine Research, Department of Geochemistry, Am Handelshafen 12, 27515 Bremerhaven, Germany

${ }^{3}$ International University Bremen, Research II, Campusring 1, 28759 Bremen, Germany

${ }^{4}$ GEOMAR, Research Center for Marine Geosciences, Wischhofstrasse 1-3, 24148 Kiel, Germany
}

\begin{abstract}
At Hydrate Ridge (HR), Cascadia convergent margin, surface sediments contain massive gas hydrates formed from methane that ascends together with fluids along faults from deeper reservoirs. Anaerobic oxidation of methane (AOM), mediated by a microbial consortium of archaea and sulfate-reducing bacteria, generates high concentrations of hydrogen sulfide in the surface sediments. The production of sulfide supports chemosynthetic communities that gain energy from sulfide oxidation. Depending on fluid flow, the surface communities are dominated either by the filamentous sulfur bacteria Beggiatoa (high advective flow), the clam Calyptogena (low advective flow), or the bivalve Acharax (diffusive flow). We analyzed surface sediments $(0$ to $10 \mathrm{~cm}$ ) populated by chemosynthetic communities for AOM, sulfate reduction (SR) and the distribution of the microbial consortium mediating AOM. Highest AOM rates were found at the Beggiatoa field with an average rate of $99 \mathrm{mmol} \mathrm{m}^{-2} \mathrm{~d}^{-1}$ integrated over 0 to $10 \mathrm{~cm}$. These rates are among the highest AOM rates ever observed in methane-bearing marine sediments. At the Calyptogena field, AOM rates were lower $\left(56 \mathrm{mmol} \mathrm{m}^{-2} \mathrm{~d}^{-1}\right)$. At the Acharax field, methane oxidation was extremely low $\left(2.1 \mathrm{mmol} \mathrm{m}^{-2} \mathrm{~d}^{-1}\right)$ and was probably due to aerobic oxidation of methane. SR was fueled largely by methane at flowimpacted sites, but exceeded AOM in some cases, most likely due to sediment heterogeneity. At the Acharax field, SR was decoupled from methane oxidation and showed low activity. Aggregates of the AOM consortium were abundant at the fluid-impacted sites (between $5.1 \times 10^{12}$ and $7.9 \times 10^{12}$ aggregates $\left.\mathrm{m}^{-2}\right)$ but showed low numbers at the Acharax field $\left(0.4 \times 10^{12}\right.$ aggregates $\left.\mathrm{m}^{-2}\right)$. A transportreaction model was applied to estimate AOM at Beggiatoa fields. The model agreed with the measured depth-integrated AOM rates and the vertical distribution. AOM represents an important methane sink in the surface sediments of HR, consuming between 50 and $100 \%$ of the methane transported by advection.
\end{abstract}

KEY WORDS: Anaerobic oxidation of methane - Methanotrophic archaea - Sulfate reduction . Gas hydrate $\cdot$ Fluid flow $\cdot$ Chemoautotrophy $\cdot$ Cold seep $\cdot$ Modeling

\section{INTRODUCTION}

At Hydrate Ridge (HR) on the Cascadia convergent margin off the coast of Oregon (USA), fluids and methane ascend along faults from deep sediments to the surface because of tectonic activity along the Juan de Fuca and North American plate convergence (Whiti- car et al. 1995, Suess et al. 1999). Under the prevailing conditions of low temperature and high hydrostatic pressure, gas hydrates form in the surface sediments at water depths between 600 and $800 \mathrm{~m}$. The hydrate composition is dominated by methane ( $\mathrm{vol} \%>95$; Suess et al. 1999). Due to the low molecular gases enclosed (methane, $\mathrm{CO}_{2}$ and $\mathrm{H}_{2} \mathrm{~S}$ ), hydrates occur as 
crystal structure 1 (Gutt et al. 1999). Hydrate-bearing surface sediments at HR are saturated with dissolved methane (around 70 mM; Torres et al. 2002). Samples of these methane-rich sediments provided the first microscopic evidence for a microbial consortium mediating anaerobic oxidation of methane (AOM) (Boetius et al. 2000b). During AOM, methane is oxidized using sulfate as an electron acceptor via the following net equation:

$$
\mathrm{CH}_{4}+\mathrm{SO}_{4}^{2-} \rightarrow \mathrm{HCO}_{3}^{-}+\mathrm{HS}^{-}+\mathrm{H}_{2} \mathrm{O}
$$

The AOM consortium predominant at HR consists of sulfate-reducing bacteria of the branch Desulfosarcina/Desulfococcus and archaea of the ANME-2 group (Boetius et al. 2000b). The archaea are surrounded by the sulfate-reducing bacteria and both grow together in dense aggregates that comprise up to $90 \%$ of the microbial biomass in hydrate-bearing sediments. The current hypothesis on the functioning of AOM assumes that archaea oxidize methane in a process that is reverse to methanogenesis (Valentine \& Reeburgh 2000, and references therein). The role of the sulfate-reducing bacteria in AOM-consortia is the oxidation of a so far unknown intermediate by simultaneous reduction of sulfate, thus maintaining thermodynamic conditions allowing methane oxidation to proceed exergonically.

Sulfate reduction (SR) rates of hydratebearing sediments at HR are extremely high compared to sediments of nearby hydrate-free sites where SR is below the detection limit, suggesting that SR is fuelled by methane rather than by organic detritus deposited from the overlying water column (Boetius et al. 2000b, Luff \& Wallmann 2003). Our study presents AOM and SR rates and the distribution of aggregates within the uppermost $10 \mathrm{~cm}$ of surface sediments at HR. One aim of this study was to investigate methane-dependent sulfate reduction within different depth zones of the hydrate-bearing sediments. Highly ${ }^{13} \mathrm{C}$ depleted archaeal-derived biomarkers suggest that methane is the primary carbon source of the AOM consortium (Elvert et al. 2001). In vitro experiments with HR sediment slurries (sediments amended with anoxic artificial seawater medium) demonstrated that SR increases with increasing methane concentration in a close 1:1 ratio with AOM (Nauhaus et al. 2002). Here, we describe the interaction between AOM and SR processes in undisturbed natural sediments of HR.
Furthermore, we investigated differences in AOM resulting from variability in the flux regime, methane concentration, and vent biota. At HR, fluid flows create distinct provinces characterized by different advection rates and by different chemosynthetic communities, utilizing hydrogen sulfide, a product of AOM, as the energy source (Sahling et al. 2002, Torres et al. 2002, Tryon et al. 2002). Our hypothesis is that the availability of methane in the different provinces has a direct influence on AOM rates. We investigated AOM at sites dominated either by sulfide-oxidizing bacteria (Beggiatoa) or symbiotic clams (Calyptogena or Acharax) via radiotracer incubations with respect to their special characteristics. Finally, a transport-reaction model (Luff \& Wallmann 2003) was applied to estimate AOM rates in Beggiatoa fields. The model input includes measured porosity and sulfate concentrations as well as the average depth distribution and density of AOM consortia at Beggiatoa fields. The agreement between modeled and measured AOM rates is discussed.

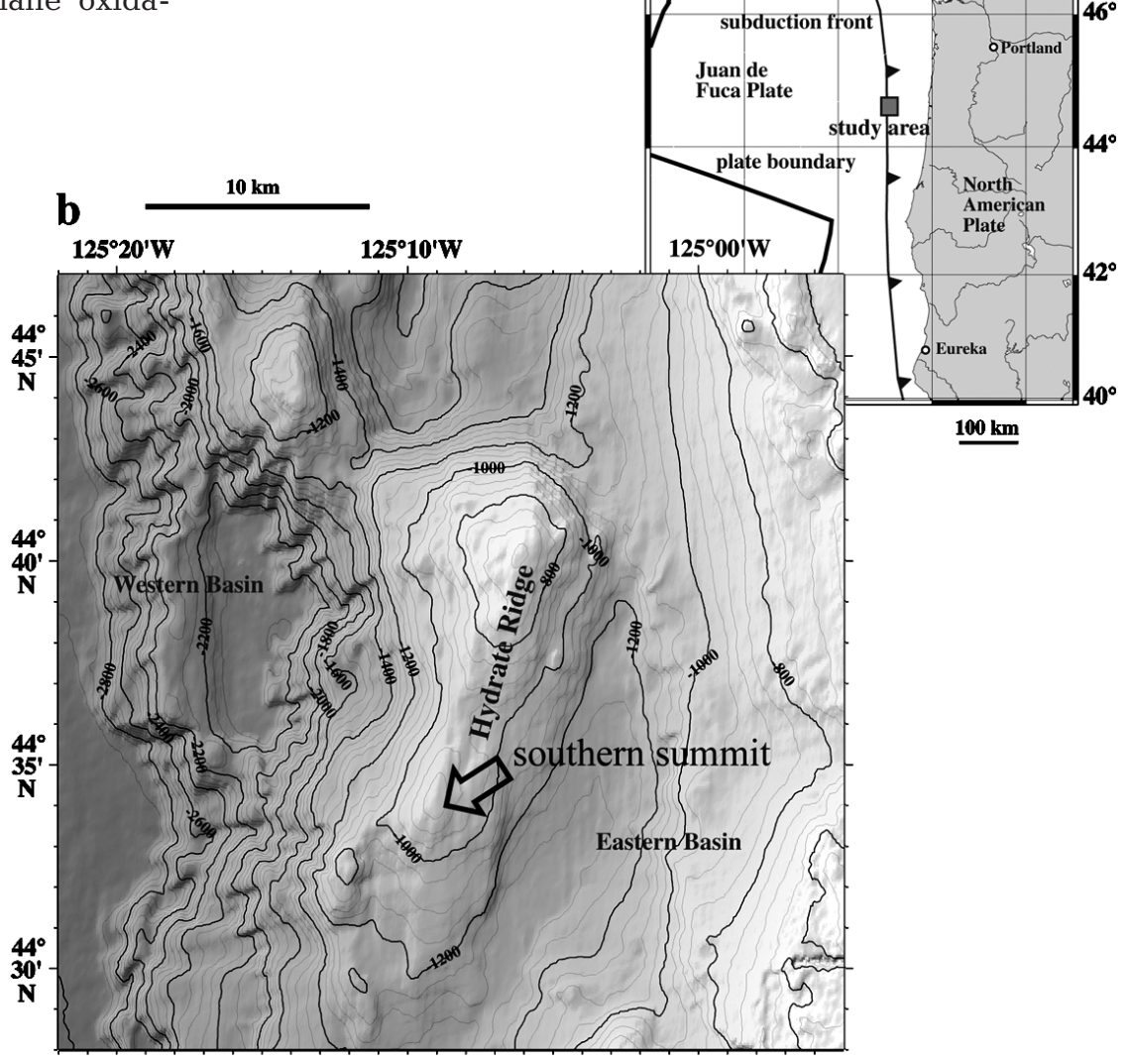

Fig. 1. (a) Location of Hydrate Ridge on the Cascadia convergent margin off the Oregon coast. (b) Topographic map of Hydrate Ridge (modified from Sommer et al. 2002) 


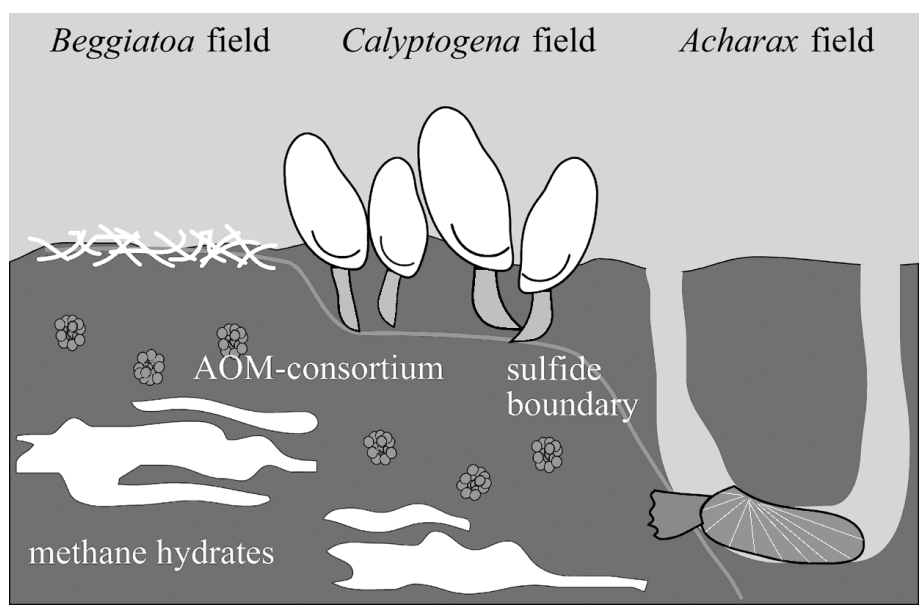

Fig. 2. Scheme of the chemosynthetic communities at Hydrate Ridge (after Sahling et al. 2002)

\section{MATERIALS AND METHODS}

Study area. Sediment samples from different chemosynthetic provinces were collected along the top of the southern summit of Hydrate Ridge during RV 'Sonne' Cruise SO-148/1 in July 2000 (Fig. 1). Referring to recent studies on fluid flow and macrofauna (Sahling et al. 2002, Torres et al. 2002, Tryon et al. 2002), the provinces at HR can be described as follows.

Gas vents: Active gas vents with rapid methane ebullition form gas plumes in the water column. The methane rises together with fluids through conduits from deeper reservoirs marked by the bottom simulating reflector (BSR) where free gas accumulates below the hydrate stability zone. The fluid-flow rate is about $10^{6}$ to $10^{7} \mathrm{~cm} \mathrm{yr}^{-1}$ during maximum discharge. The methane content of the discharging gas is $99 \%$.

Beggiatoa fields: Dense mats of filamentous chemosynthetic bacteria (Beggiatoa spp.) form white patches on surface sediments of decimeters to decameters in scale (Fig. 2). Methane hydrates, formed during transient gas injection, are located in the uppermost sediment layers. Fluid flows are directed upward at rates of 10 to $250 \mathrm{~cm} \mathrm{yr}^{-1}$. The dissolved methane is in equilib- rium with methane hydrates. Hydrogen sulfide is present in high amounts (up to $26 \mathrm{mM}$ ) in the top $5 \mathrm{~cm}$ of the sediment.

Calyptogena fields: Vesicomyid clams (Calyptogena spp.), which harbor chemosynthetic bacteria in their gills, cover surface sediments in fields of meters to decameters in scale. These fields are either adjacent to Beggiatoa fields or occur separately. Whereas gas vents and Beggiatoa fields are presumably directly coupled to deeper flow systems, the processes at Calyptogena fields may only peripherally be linked to fluid-flow conduits. Here, an upward fluidflow rate of 2 to $10 \mathrm{~cm} \mathrm{yr}^{-1}$ occurs alternatively with periods of seawater downflow caused by the pumping activity of the clams. High concentrations of hydrogen sulfide $(>10 \mathrm{mM})$ occur below $5 \mathrm{~cm}$ sediment depth.

Acharax fields: The solemyid bivalve Acharax sp. harbors chemosynthetic bacteria in their gills. In contrast to Calyptogena, these bivalves live in the sediment in U-shaped burrows connected at both ends to the sediment surface. Acharax fields are located marginal to Calyptogena fields relative to the seeps, and the bivalves are hypothesized to 'mine' the sediment to meet their hydrogen sulfide demand. Hydrogen sulfide is not present in the upper $15 \mathrm{~cm}$ and increases at low levels ( 0.1 to $0.3 \mathrm{mM}$ ) within 15 to 25 $\mathrm{cm}$.

Sampling. Surface sediments from chemosynthetic communities (Beggiatoa, Calyptogena and Acharax fields) were obtained using a video-guided multicorer equipped with 4 cores. After recovery, cores were immediately transferred to a cold $\left(4^{\circ} \mathrm{C}\right)$ laboratory.

Field measurements: Samples were taken from 2 Beggiatoa, 1 Caplytogena, and 1 Acharax field (Table 1). Three cores per deployment were subsampled vertically with push-cores (acrylic core liners with an inner diameter of $26 \mathrm{~mm}$ ) for measurements of AOM and SR ( 3 to 5 replicates each). Hence, average values from 1 station represent an area of almost $1 \mathrm{~m}^{2}$. Using a whole core injection (WCI) method (Jørgensen 1978), radioactive tracers, i.e. ${ }^{14} \mathrm{CH}_{4}$ (dissolved in water,

Table 1. Station data of investigated provinces during RV 'Sonne' Cruise 148/1. WCI: whole core injection; S: sulfate; P: porosity; A: aggregates; M: modeling

\begin{tabular}{|lccccc|}
\hline Stn & Province & Date & Position & Depth (m) & Methods and measurements \\
\hline $19-2$ & Beggiatoa field (1) & 27 July 2000 & $44^{\circ} 34.104 \mathrm{~N}, 125^{\circ} 08.807 \mathrm{~W}$ & 777 & WCI, S, P, A, M \\
14 & Beggiatoa field (2) & 26 July 2000 & $44^{\circ} 34.218 \mathrm{~N}, 125^{\circ} 08.804 \mathrm{~W}$ & 777 & WCI, S, P, A, M \\
28 & Beggiatoa field (3) & 28 July 2000 & $44^{\circ} 34.196 \mathrm{~N}, 125^{\circ} 08.816 \mathrm{~W}$ & 777 & In vitro stoichiometry \\
29 & Beggiatoa field (4) & 28 July 2000 & $44^{\circ} 34.222 \mathrm{~N}, 125^{\circ} 08.834 \mathrm{~W}$ & 777 & In vitro stoichiometry \\
38 & Calyptogena field & 30 July 2000 & $44^{\circ} 34.186 \mathrm{~N}, 125^{\circ} 08.847 \mathrm{~W}$ & 787 & WCI, S, P, A \\
51 & Acharax field & 01 Aug 2000 & $44^{\circ} 34.198 \mathrm{~N}, 125^{\circ} 08.858 \mathrm{~W}$ & 775 & WCI, S, P, A \\
\hline
\end{tabular}


injection volume $10 \mu \mathrm{l}$, activity $1 \mathrm{kBq}$ ) and ${ }^{35} \mathrm{SO}_{4}$ (dissolved in water, injection volume $6 \mu \mathrm{l}$, activity $50 \mathrm{kBq}$ ), were each injected into separate replicate push-cores at $1 \mathrm{~cm}$ depth intervals to obtain rates of $\mathrm{AOM}$ and $\mathrm{SR}$, respectively. The replicates were incubated on board at in situ temperature $\left(4\right.$ to $5^{\circ} \mathrm{C}$, Suess et al. 1999) for $24 \mathrm{~h}$ in the dark. To stop bacterial activity, the upper $10 \mathrm{~cm}$ of the sediment cores were sectioned into $1 \mathrm{~cm}$ intervals and mixed with $25 \mathrm{ml}$ sodium hydroxide $(2.5 \% \mathrm{w} / \mathrm{w})$ or $20 \mathrm{ml}$ zinc acetate $(20 \% \mathrm{w} / \mathrm{w})$ for AOM and SR, respectively. The samples from control push-cores were fixed before tracer addition. Fixed AOM samples were stored at $4^{\circ} \mathrm{C}$ in heatwelded, gas-tight bags (4 layers: $80 \mu \mathrm{m}$ nylon, $6 \mu \mathrm{m}$ ethylenevinyl alcohol, $80 \mu \mathrm{m}$ nylon, $160 \mu \mathrm{m}$ polyethylene) without headspace. Fixed SR samples were stored in $50 \mathrm{ml}$ Corning vials.

Potential rates: To insure that the applied short-term radiotracer incubation method is suitable to quantify the ratio between $\mathrm{AOM}$ and $\mathrm{SR}$, we compared the method with a long-term in vitro incubation method (Nauhaus et al. 2002). By the latter method, AOM and SR rates are calculated, over long time periods (2 mo), from the simultaneous decrease of methane and the production of sulfide, respectively. Samples were taken from the 1 to $4 \mathrm{~cm}$ horizon in 2 Beggiatoa cores (Table 1). The sediment was stored anoxically in glass bottles without headspace at $4{ }^{\circ} \mathrm{C}$ until the experiment started. Radioactive tracers, i.e. ${ }^{14} \mathrm{CH}_{4}$ (dissolved in water, injection volume $50 \mu \mathrm{l}$, activity $13 \mathrm{kBq}$ ) and ${ }^{35} \mathrm{SO}_{4}$ (dissolved in water, injection volume $10 \mu \mathrm{l}$, activity $100 \mathrm{kBq}$ ), were each injected into 5 gas-tight glass syringes filled with $4 \mathrm{~cm}^{3}$ sediment slurry, and incubated for $27 \mathrm{~h}$ at $12^{\circ} \mathrm{C}$. A description of the preparation of the sediment slurry is given in Nauhaus et al. (2002). The incubation temperature corresponded to the temperature optimum of the AOM consortium at this site (Nauhaus et al. 2002). The glass syringes were filled under an anoxic atmosphere of $\mathrm{N}_{2}$ and sealed without introducing gas bubbles. At the beginning of the incubation, the methane and sulfate concentration of the slurry pool was $0.82 \mathrm{mmol} \mathrm{l}^{-1}$ sediment and $14.5 \mathrm{mmol} \mathrm{l}^{-1}$ pore water, respectively. The slurry contained $0.2 \mathrm{~g}$ dry sediment $\mathrm{cm}^{-3}$. After incubation the activity was stopped as described for whole-core injection and samples were transferred into $50 \mathrm{ml}$ glass bottles and closed quickly with rubber stoppers $(1.5 \mathrm{~cm}$ thickness). The glass bottles were shaken thoroughly to equilibrate the pore water methane between aqueous and gas phases. Controls were fixed before tracer addition.

Analytical procedures. Methane analysis: AOM samples were transferred from gas-tight bags into $50 \mathrm{ml}$ glass bottles. The glass bottles were closed quickly with rubber stoppers and shaken thoroughly as described above. To measure the total methane concentration of the sample, a $200 \mu \mathrm{l}$ aliquot of the headspace was injected into a gas chromatograph (5890A, Hewlett Packard) equipped with a packed stainless steal Porapak-Q column (6 ft, 0.125 in, 80/100 mesh, Agilent Tecknologie) and a flame ionization detector. The carrier gas was helium at a flow rate of $30 \mathrm{ml}$ $\mathrm{min}^{-1}$. The column temperature was $40^{\circ} \mathrm{C}$.

Measurement of ${ }^{14} \mathrm{CH}_{4}$ : To measure ${ }^{14} \mathrm{CH}_{4}$, a slightly modified method of Iversen \& Blackburn (1981) was used. The complete headspace of the sample was purged by a slow flow $\left(25 \mathrm{ml} \mathrm{min}^{-1}\right)$ of artificial air through a heated $\left(850^{\circ} \mathrm{C}\right)$ quartz tube filled with $\mathrm{Cu}(\mathrm{II})$-oxide. In the tube, the ${ }^{14} \mathrm{CH}_{4}$ was oxidized to ${ }^{14} \mathrm{CO}_{2}$, which was captured in 2 successive scintillation vials $(20 \mathrm{ml})$ filled with a mixture of $1 \mathrm{ml}$ phenylethylamine and $7 \mathrm{ml}$ ethyleneglycolmonomethylether. After the addition of $10 \mathrm{ml}$ scintillation cocktail (Ultima Gold XR, Packard), the sample activity was measured by scintillation counting (2500TR LSC, Packard).

Measurement of ${ }^{14} \mathrm{CO}_{2}$ (diffusion method): To determine the amount of microbially produced ${ }^{14} \mathrm{CO}_{2}$, a modified method of Boetius et al. (2000a) was used. The sample was quantitatively transferred into a $100 \mathrm{ml}$ glass bottle. One drop of antifoam and $1 \mathrm{ml}$ of bromothymol blue (transition range $\mathrm{pH} 5.8$ to $\mathrm{pH}$ 7.6, yellow-blue) were added to avoid foaming and to check the sample $\mathrm{pH}$. As a trap for $\mathrm{CO}_{2}$, a scintillation vial $(20 \mathrm{ml})$ was prepared with a folded filter (\#1001824, grade 1, Whatman) wetted with $4 \mathrm{ml}$ phenylethylamine and placed on top of the sample inside the glass. The glass was closed with a rubber stopper (butyl, thickness $2 \mathrm{~cm}$ ) and fixed with a screw $\mathrm{cap}_{i} 6 \mathrm{ml}$ of hydrochloric acid (6M) was injected through the rubber stopper to degas the $\mathrm{CO}_{2}$. The sample was left for $48 \mathrm{~h}$ to capture the escaped ${ }^{14} \mathrm{CO}_{2}$ on the filter. After $24 \mathrm{~h}$, the $\mathrm{pH}$ was checked visually and hydrochloric acid was added if the $\mathrm{pH}$ of the sample had become alkaline. After $48 \mathrm{~h}$, the scintillation vial was removed and $6 \mathrm{ml}$ ethanol was added to dissolve crusts formed by the reaction of $\mathrm{CO}_{2}$ with phenyethylamine. After dissolution, $10 \mathrm{ml}$ scintillation cocktail (Ultima Gold XR, Packard) was added and the activity of the sample was measured by scintillation counting (2500TR LSC, Packard). This method produced an average ${ }^{14} \mathrm{CO}_{2}$ recovery of $98 \%$ in prior tests.

Calculation of AOM: AOM rates were calculated by the following equation:

$$
\mathrm{AOM}=\frac{{ }^{14} \mathrm{CO}_{2} \times \mathrm{CH}_{4}}{{ }^{14} \mathrm{CH}_{4} \times V \times t}
$$

where ${ }^{14} \mathrm{CO}_{2}$ is the activity of the produced radioactive carbon dioxide, $\mathrm{CH}_{4}$ is the total amount of methane in 
the sample, ${ }^{14} \mathrm{CH}_{4}$ is the activity of the radioactive methane, $v$ is the volume of the sediment, and $t$ is the incubation time. This calculation is based on the ratio of methane to radioactive methane. It is assumed that any losses of $\mathrm{CH}_{4}$ during incubation or storage occur at the same ratio for ${ }^{14} \mathrm{CH}_{4}$ as for ${ }^{12} \mathrm{CH}_{4}$.

Sulfate analysis: Samples were taken vertically with a push-core (inner diameter $26 \mathrm{~mm}$; Table 1) from one core of each multicorer haul. Pore-water sulfate concentrations were measured using nonsuppressed ion chromatography with an autosampler (Spark Holland Basic and Marathon, injection volume $50 \mu \mathrm{l}$ ), an anion exchange column (LCA A14, Sykam) and a conductivity detector (S3110, Sykam). The eluant was a $7.5 \mathrm{mM} \mathrm{Na}_{2} \mathrm{CO}_{3}$ solution. The flow rate was set to $1.75 \mathrm{ml} \mathrm{min}^{-1}$.

Sediment porosity: Samples were taken vertically with a push-core (inner diameter $26 \mathrm{~mm}$; Table 1) from one core of the multicorer. Porosity was determined by drying a known volume of sediment. The wet sediment was weighed, lyophilized, and weighed again. From the difference of the 2 weights, the proportion of sediment dry mass and the porosity was calculated.

Sulfate reduction analysis: SR rates were determined using the single step acidic Cr-II method according to Fossing \& Jørgensen (1989).

Bacterial counts: Samples were taken vertically with a push-core (inner diameter $26 \mathrm{~mm}$ ) from one of the 3 cores which were also sampled for AOM and SR. The push-core was split into $1 \mathrm{~cm}$ intervals; $1 \mathrm{~cm}^{3}$ of sediment from each depth interval was transferred into vials filled with $9 \mathrm{ml}$ formaldehyde $(2 \%$ in seawater, $0.22 \mu \mathrm{m}$ filtered) and stored at $4^{\circ} \mathrm{C}$. Aggregates of the AOM consortium were counted by applying acridine orange direct counts (AODC) according to Meyer-Reil (1983) as modified by Boetius \& Lochte (1996). The consortia have a specific size and shape that can easily be recognized under the microscope when stained with AODC (Boetius et al. 2000b). In Hydrate Ridge sediments, nearly all cell aggregations have been identified as AOM consortia by a detailed study using fluorescence in situ hybridization (Knittel et al. 2003). Hence, at this location the simpler method of AODC counts can be used to obtain quantitative numbers of consortia in these sediments.

Numerical transport-reaction model. A transportreaction model was applied for Beggiatoa fields 1 and 2 (Table 1) to estimate the change of methane concentrations over time in the surface sediments of these open and dynamic sedimentary environments. The model considers molecular diffusion and advection of dissolved sulfate and methane, and the specific rate of AOM. It is based on a system of 2 coupled differential equations (Eqs. 3 \& 4) describing the concentrationdepth profiles of dissolved sulfate and methane:
$\Phi \frac{\partial\left[\mathrm{SO}_{4}^{2-}\right]}{\partial t}=\frac{\partial\left(\Phi \frac{D_{S}}{\Theta^{2}} \times \frac{\partial\left[\mathrm{SO}_{4}^{2-}\right]}{\partial x}\right)}{\partial x}-\Phi V \frac{\partial\left[\mathrm{SO}_{4}^{2-}\right]}{\partial x}-\Phi R_{\mathrm{AOM}}$
$\Phi \frac{\partial\left[\mathrm{CH}_{4}\right]}{\partial t}=\frac{\partial\left(\Phi \frac{D_{M}}{\Theta^{2}} \times \frac{\partial\left[\mathrm{CH}_{4}\right]}{\partial x}\right)}{\partial x}-\Phi V \frac{\partial\left[\mathrm{CH}_{4}\right]}{\partial x}-\Phi R_{\mathrm{AOM}}$

where $t$ is time, $x$ is sediment depth, $\left[\mathrm{CH}_{4}\right]$ and $\left[\mathrm{SO}_{4}{ }^{2-}\right]$ are concentrations of dissolved methane and sulfate in sediment pore-waters, $D_{S}$ and $D_{M}$ are molecular diffusion coefficients of sulfate and methane, $\Phi$ and $\Theta$ are sediment porosity and tortuosity, $v$ is the velocity of vertical fluid flow, and $R_{\mathrm{AOM}}$ is the specific rate of AOM.

Sediment porosity changes with depth due to sediment compaction. The depth profile is approximated using the following exponential function (Berner 1980):

$$
\Phi=\Phi_{f}+\left(\Phi_{i}-\Phi_{f}\right) \mathrm{e}^{-p x}
$$

where the parameter values for $\Phi_{f}$ (porosity at infinite depth), $\Phi_{i}$ (porosity at zero depth), and $p$ (attenuation coefficient for the exponential decrease of porosity with depth) are determined by fitting the porosity model to the corresponding porosity data.

Sediment tortuosity was calculated from porosity using the following empirical relation (Boudreau 1997):

$$
\Theta^{2}=1-\ln \left(\Phi^{2}\right)
$$

The rate of vertical fluid flow was calculated considering sediment burial, steady state compaction, and upward flow of deep-derived vent fluids (Luff \& Wallmann 2003):

$$
V=\frac{W_{f} \Phi_{f}-V_{i} \Phi_{i}}{\Phi}
$$

where $w_{f}$ is sedimentation rate and $v_{i}$ the rate of fluid flow at the sediment water interface. The fluid-flow velocity can be determined by fitting the model curves to measured sulfate pore-water profiles (Luff \& Wallmann 2003).

The kinetic rate law for AOM was derived using recently published experimental data (Nauhaus et al. 2002) and unpublished results (K. Nauhaus pers. comm.). Ongoing incubation studies show that specific $\mathrm{AOM}$ rates $\left(R_{\mathrm{AOM}}\right)$ are accelerated at high methane concentrations while the concentration of sulfate has no significant effect on the rate as long as sulfate concentration is greater than approximately 1 to $2 \mathrm{mM}$. A reasonable first order approximation of the rate law might thus be:

$$
R_{\mathrm{AOM}}=k_{\mathrm{AOM}}[\mathrm{CON}]\left[\mathrm{CH}_{4}\right] \frac{\left[\mathrm{SO}_{4}^{2-}\right]}{K_{s}+\left[\mathrm{SO}_{4}^{2-}\right]}
$$

where $k_{\mathrm{AOM}}$ is a kinetic constant, [CON] is the concentration of aggregates of the AOM consortium and $K_{s}$ is a 
Monod constant $\left(K_{s}=1 \mathrm{mM}\right)$ defining the inhibition of AOM at low sulfate concentrations (Nauhaus et al. 2002). Nauhaus et al. (2002) determined an AOM rate of $5 \mathrm{~mol} \mathrm{~g}^{-1}$ dry wt d $\mathrm{d}^{-1}$ in an experimental incubation of sediments taken from an active vent site at the crest of the southern Hydrate Ridge during RV 'Sonne' expedition 148. Prior to incubation, sediments were mixed with anoxic seawater to obtain a slurry with 0.2 to $0.3 \mathrm{~g}$ dry sediment $\mathrm{cm}^{-3}$. The methane concentration in the slurry was approximately $15 \mathrm{mM}$ and the slurry contained on average $9 \times 10^{7}$ aggregates per g sediment dry wt (Nauhaus et al. 2002). From these data, the value of the kinetic constant $k_{\mathrm{AOM}}$ can be derived as $3.7 \times 10^{-9} \mathrm{~cm}^{3} \mathrm{~d}^{-1}$.

Boundary conditions were defined at the interface between surface sediment and overlying Beggiatoa mat and at the base of the model column at $20 \mathrm{~cm}$ sediment depth (Table 2). At the upper boundary, sulfate and methane concentrations were set to constant values corresponding to seawater concentrations $\left(\left[\mathrm{CH}_{4}\right](\mathrm{x}=0)=\mathrm{M} 0=0 \mathrm{mM},\left[\mathrm{SO}_{4}{ }^{2-}\right](\mathrm{x}=0)=\mathrm{S} 0=29 \mathrm{mM}\right)$. At the lower boundary the concentrations were set to constant values corresponding to the concentrations prevailing in the rising vent fluids $\left(\left[\mathrm{CH}_{4}\right](\mathrm{x}=20)=\mathrm{ML}=\right.$ $\left.68 \mathrm{mM},\left[\mathrm{SO}_{4}{ }^{2-}\right](\mathrm{x}=20)=\mathrm{SL}=0 \mathrm{mM}\right)$. The rising fluids were assumed to be in equilibrium with gas hydrates due to the widespread occurrence of hydrates in HR sediments. Therefore, the methane concentration applied at the lower boundary corresponds to the saturation value at the pressure and temperature conditions prevailing at HR (Luff \& Wallmann 2003).

The model was run to steady state starting from arbitrary initial conditions. Due to the high reaction rates and flow velocities, steady state was usually attained within a few years. Mathematica version 4.1 was used to implement the model and Mathematica's NDSolve object was applied for the numerical integration of the differential equations. NDSolve uses the Method-ofLines code for integration, a finite difference procedure which has been frequently applied in the modeling of early diagenetic processes (Boudreau 1996, Luff et al. 2000, Luff \& Wallmann 2003).

\section{RESULTS}

\section{Field measurements}

\section{Beggiatoa field 1}

AOM reached a maximum rate of $0.24 \mu \mathrm{mol} \mathrm{cm} \mathrm{cm}^{-3} \mathrm{~d}^{-1}$ (Fig. 3a) between 4 and $5 \mathrm{~cm}$ sediment depth. Peaks of
AOM in replicate cores (>0.04 $\mu$ mol $\mathrm{cm}^{-3} \mathrm{~d}^{-1}, \mathrm{n}=3$ ) were distributed between 2 and $7 \mathrm{~cm}$. In all replicates, AOM was low in the uppermost centimeter of the sediment (around $0.02 \mu \mathrm{mol} \mathrm{cm} \mathrm{cm}^{-3} \mathrm{~d}^{-1}$ ). Integrated over 0 to $10 \mathrm{~cm}$ sediment depth, the mean AOM was $5.1( \pm 4.4, \mathrm{n}=3) \mathrm{mmol} \mathrm{m}^{-2} \mathrm{~d}^{-1}$ (Table 3$)$. SR was an order of magnitude higher than AOM (with a maximum rate of $2.07 \mu \mathrm{mol} \mathrm{cm} \mathrm{cm}^{-3} \mathrm{~d}^{-1}$ between 4 and $5 \mathrm{~cm}, \mathrm{n}=5$ ), but followed a similar depth pattern. Three replicates showed peaks (>0.4 $\mu$ mol $\mathrm{cm}^{-3} \mathrm{~d}^{-1}$ ) between 3 and $6 \mathrm{~cm}$. All replicates had low rates at the sediment surface (around $0.12 \mu \mathrm{mol} \mathrm{cm} \mathrm{cm}^{-3} \mathrm{~d}^{-1}$ ), except for 1 replicate that showed high activity $\left(1.55 \mu \mathrm{mol} \mathrm{cm} \mathrm{cm}^{-3} \mathrm{~d}^{-1}\right)$ between 0 and $1 \mathrm{~cm}$. One replicate had comparably low

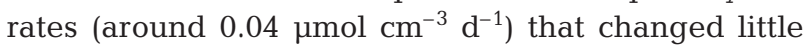
over depth. Although most of the SR replicates had similar depth patterns, the magnitude of SR peaks varied between 0.12 and $2.07 \mu \mathrm{mol} \mathrm{cm} \mathrm{cm}^{-3} \mathrm{~d}^{-1}$. Integrated over 0 to $10 \mathrm{~cm}$ sediment depth, the mean SR was 32 $( \pm 34, \mathrm{n}=5) \mathrm{mmol} \mathrm{m} \mathrm{m}^{-2} \mathrm{~d}^{-1}$. Sulfate concentration decreased from $27.1 \mathrm{mM}$ at the sediment surface to $2.0 \mathrm{mM}$ at $6 \mathrm{~cm}$, below which no further decrease was measured. At this depth SR reached a constant low

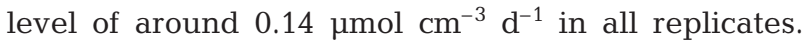
Aggregate counts peaked at a mean of $1.27 \times 10^{8} \mathrm{~cm}^{-3}$ between 3 and $4 \mathrm{~cm}$. Counts were lower at the sediment surface $\left(0.51 \times 10^{8} \mathrm{~cm}^{-3}\right)$ and below $6 \mathrm{~cm}$ (around $0.30 \times 10^{8} \mathrm{~cm}^{-3}$ ). Integrated over 0 to $10 \mathrm{~cm}$ sediment depth, $6.1( \pm 3.4) \times 10^{12}$ aggregates $\mathrm{m}^{-2}$ inhabited the sediment.

Table 3. AOM, SR and aggregate counts integrated over 0 to $10 \mathrm{~cm}$ sediment depth. Standard deviations are given

\begin{tabular}{|lccc|}
\hline Field & $\begin{array}{c}\mathrm{AOM} \\
\left(\mathrm{mmol} \mathrm{m}^{-2} \mathrm{~d}^{-1}\right)\end{array}$ & $\begin{array}{c}\mathrm{SR} \\
\left(\mathrm{mmol} \mathrm{m}^{-2} \mathrm{~d}^{-1}\right)\end{array}$ & $\begin{array}{c}\text { Aggregates } \\
\left(10^{12} \mathrm{~m}^{-2}\right)\end{array}$ \\
\hline Beggiatoa (1) & $5.1 \pm 4.4$ & $32 \pm 34$ & $6.1( \pm 3.4)$ \\
Beggiatoa (2) & $99 \pm 102$ & & $5.1( \pm 3.0)^{*}$ \\
Calyptogena & $56 \pm 54$ & $65 \pm 58$ & $7.9( \pm 5.3)$ \\
Acharax & $2.1 \pm 1.4$ & $0.4 \pm 0.3$ & $0.4( \pm 0.6)$ \\
${ }^{*}$ Integrated over 0 to 8 $\mathrm{cm}$ sediment depth & \\
\hline
\end{tabular}


a) Beggiatoa field 1
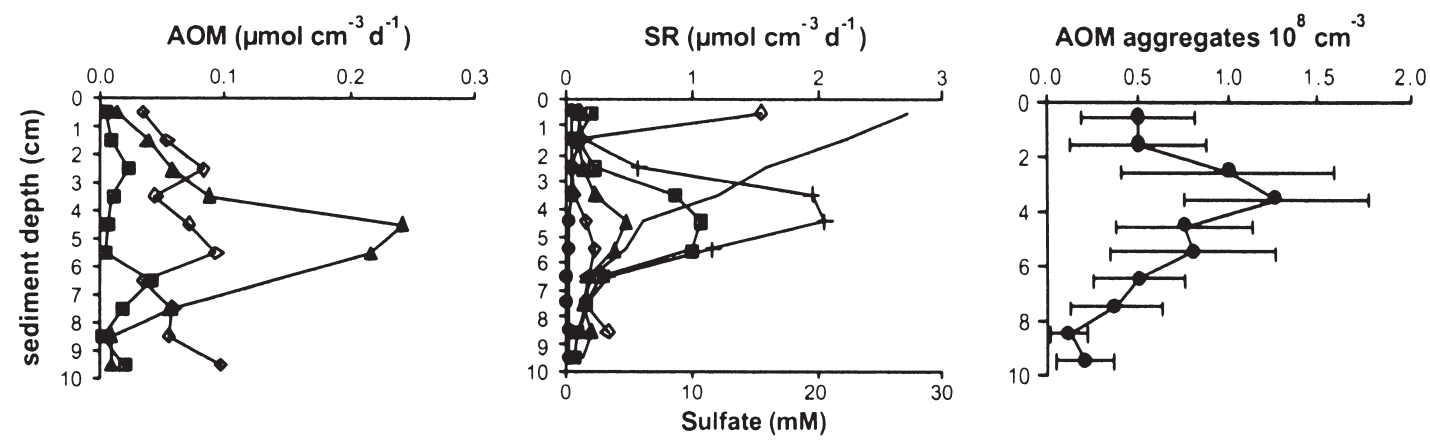

\section{b) Beggiatoa field 2}
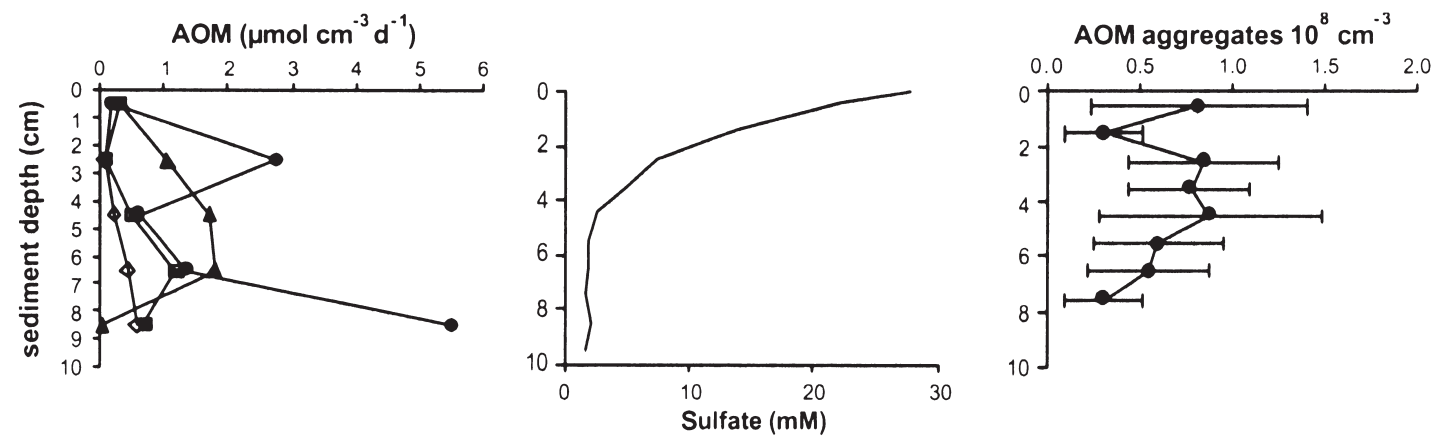

\section{c) Calyptogena field}
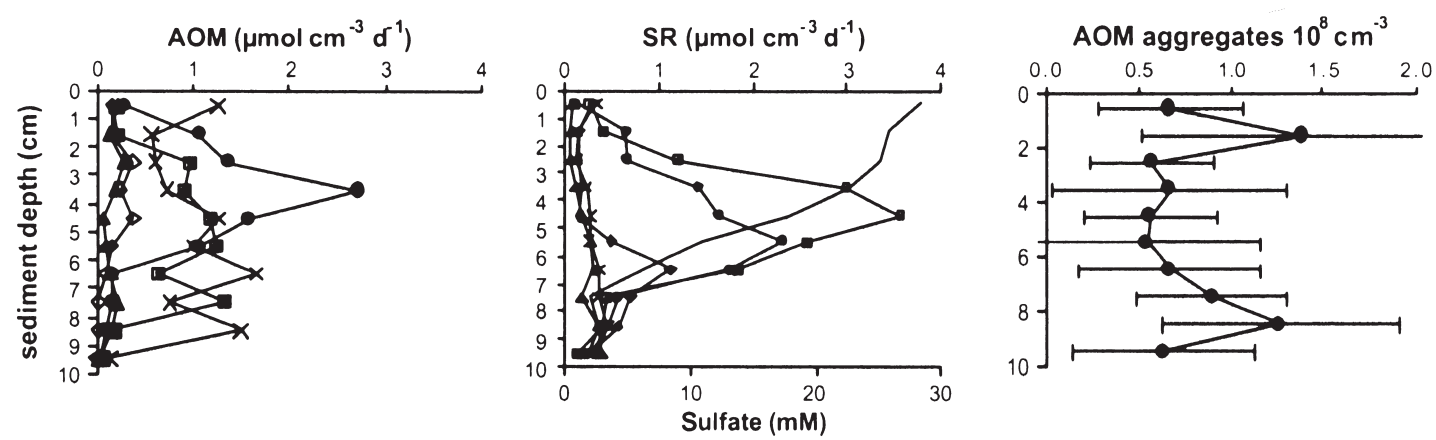

\section{d) Acharax field}
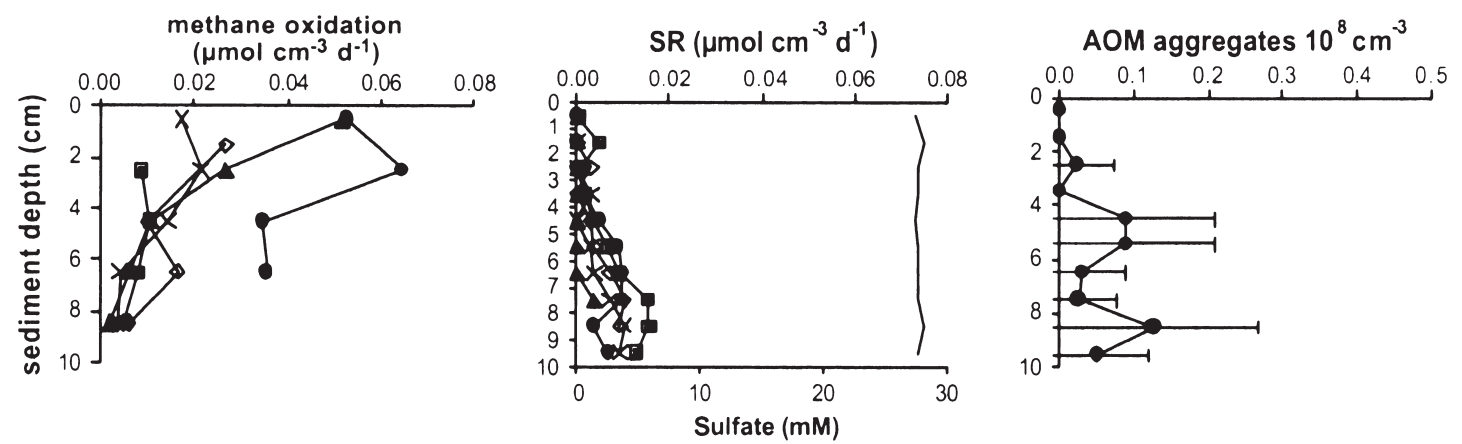

Fig. 3. AOM and SR rate, sulfate concentration (-) and aggregate density (mean \pm SD of counted grids; $\mathrm{n}=25,17,30$ and 20 , respectively) of (a) Beggiatoa field 1 and (b) 2, (c) Calyptogena field and (d) Acharax field. For Beggiatoa field 2 no SR was measured. Each replicate is represented by a different symbol 


\section{Beggiatoa field 2}

Here, AOM reached a maximum rate of $5.5 \mu \mathrm{mol}$ $\mathrm{cm}^{-3} \mathrm{~d}^{-1}$ between 8 and $9 \mathrm{~cm}$ (Fig. 3b). These are the highest rates measured among all investigated provinces. The 4 replicates showed different profiles and magnitudes of activity. In some cases AOM increased beneath $2 \mathrm{~cm}$ sediment depth. One replicate had a peak between 2 and $3 \mathrm{~cm}$ as well as between 8 and $9 \mathrm{~cm}$. In all replicates, AOM was low at the sediment surface. Integrated over 0 to $10 \mathrm{~cm}$, the mean AOM rate was $99( \pm 102, \mathrm{n}=4) \mathrm{mmol} \mathrm{m}^{-2}$ $\mathrm{d}^{-1}$. Sulfate was depleted from $27.9 \mathrm{mM}$ at the sediment surface to $2.6 \mathrm{mM}$ between 4 and $5 \mathrm{~cm}$ and stayed constant around $1.8 \mathrm{mM}$ below this depth. Unfortunately, SR was not measured at this station. Aggregate counts were the highest between 2 and $5 \mathrm{~cm}$ with around $0.84 \times 10^{8} \mathrm{~cm}^{-3}$. Another peak $\left(0.82 \times 10^{8} \mathrm{~cm}^{-3}\right)$ was located at the sediment surface. Integrated over 0 to $8 \mathrm{~cm}$ sediment depth, $5.1( \pm 3.0) \times 10^{12}$ aggregates $\mathrm{m}^{-2}$ inhabited the sediment.

\section{Calyptogena field}

Rates of AOM and SR were variable between replicates as observed in Beggiatoa field 1. AOM rates of the 5 replicates were within the range of those observed in the Beggiatoa samples (Fig. 3c). Rates reached a maximum of $2.70 \mu \mathrm{mol} \mathrm{cm} \mathrm{cm}^{-3} \mathrm{~d}^{-1}$ between 3 and $4 \mathrm{~cm}$. Except for one replicate that showed a distinct maximum between 2 and $5 \mathrm{~cm}$, peaks were difficult to define for the other replicates. In some cores, AOM increased sharply $(>0.30 \mu \mathrm{mol}$ $\mathrm{cm}^{-3} \mathrm{~d}^{-1}$ ) beneath the surface and decreased again towards the deepest layer. In all replicates, AOM

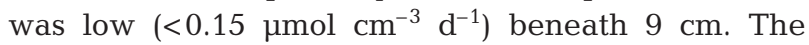
same was true for the topmost layer $(<0.30 \mu \mathrm{mol}$ $\mathrm{cm}^{-3} \mathrm{~d}^{-1}$ ) except for one replicate that exhibited a rate of $1.26 \mu \mathrm{mol} \mathrm{cm} \mathrm{cm}^{-3} \mathrm{~d}^{-1}$. Integrated over a 0 to $10 \mathrm{~cm}$ sediment depth, mean AOM was $56 \quad( \pm 54$, $\mathrm{n}=5) \mathrm{mmol} \mathrm{m} \mathrm{m}^{-2} \mathrm{~d}^{-1}$. SR reached a maximum of $3.56 \mu \mathrm{mol} \mathrm{cm} \mathrm{c}^{-3} \mathrm{~d}^{-1}$ between 4 and $5 \mathrm{~cm}(\mathrm{n}=5)$. In 3 replicates, distinct peaks $\left(>1 \mu \mathrm{mol} \mathrm{cm} \mathrm{cm}^{-3} \mathrm{~d}^{-1}\right)$ were observed between 3 and $8 \mathrm{~cm}$. Two replicates remained low compared to the others (around $0.26 \mu \mathrm{mol} \mathrm{cm} \mathrm{cm}^{-3}$ $\mathrm{d}^{-1}$ ) over the whole depth profile. At the surface as well as beneath $8 \mathrm{~cm}$, SR dropped below 0.30 and $0.50 \mu \mathrm{mol} \mathrm{cm} \mathrm{cm}^{-3} \mathrm{~d}^{-1}$, respectively. Integrated over a 0 to $10 \mathrm{~cm}$ sediment depth, the mean SR was 65 $( \pm 58, \mathrm{n}=5) \mathrm{mmol} \mathrm{m} \mathrm{m}^{-2} \mathrm{~d}^{-1}$. Comparing integrated rates of $\mathrm{AOM}$ and $\mathrm{SR}$, a ratio of about 1:1 was observed. Sulfate concentration decreased continuously between 3 and $8 \mathrm{~cm}$ from 25.1 to $2.0 \mathrm{mM}$. Below
$8 \mathrm{~cm}$, sulfate concentration appeared to stay constant around $2 \mathrm{mM}$. Aggregate counts peaked between 1 and $2 \mathrm{~cm}\left(1.39 \times 10^{8} \mathrm{~cm}^{-3}\right)$ as well as between 8 and $9 \mathrm{~cm}\left(1.27 \times 10^{8} \mathrm{~cm}^{-3}\right)$. Above, between and below these maxima, aggregate counts were around $0.65 \times$ $10^{8} \mathrm{~cm}^{-3}$. Integrated over a 0 to $10 \mathrm{~cm}$ sediment depth, $7.9( \pm 5.3) \times 10^{12}$ aggregates $\mathrm{m}^{-2}$ inhabited the sediment.

\section{Acharax field}

Methane oxidation, SR and aggregate profiles differed considerably from those at the Beggiatoa and Calyptogena fields. Methane oxidation reached a

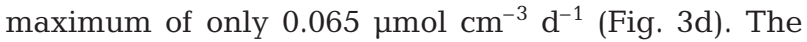
highest rates of all replicates were located at the top of the sediment and decreased with depth. Mean methane oxidation was $2.1( \pm 1.4, \mathrm{n}=5) \mathrm{mmol} \mathrm{m}^{-2} \mathrm{~d}^{-1}$ integrated over 0 to $10 \mathrm{~cm}$. SR reached a maximum of only $0.0016 \mu \mathrm{mol} \mathrm{cm} \mathrm{cm}^{-3} \mathrm{~d}^{-1}$. No SR was found at the

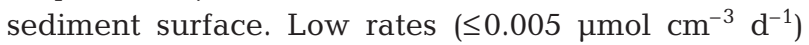
were detected between 1 and $5 \mathrm{~cm}$. Below $5 \mathrm{~cm}, \mathrm{SR}$ increased continuously with depth and reached a maximum between 7 and $9 \mathrm{~cm}$. Integrated over 0 to $10 \mathrm{~cm}$ sediment depth, the mean SR was $0.4( \pm 0.3, \mathrm{n}=5)$ $\mathrm{mmol} \mathrm{m} \mathrm{m}^{-2} \mathrm{~d}^{-1}$. Sediment sulfate concentration was $27.8 \mathrm{mM}$ and did not change over the whole sediment profile. Except for the depth section between 2 and $3 \mathrm{~cm}$, no aggregates were found in the uppermost $4 \mathrm{~cm}$. Below $4 \mathrm{~cm}$, mean aggregate counts increased up to $0.13 \times 10^{8} \mathrm{~cm}^{-3}$ between 8 and $9 \mathrm{~cm}$. Integrated over 0 to $10 \mathrm{~cm}$ sediment depth, only $0.4( \pm 0.6) \times$ $10^{12}$ aggregates $\mathrm{m}^{-2}$ inhabited the sediment.

\section{Potential rates}

Potential rates of $\mathrm{AOM}$ and $\mathrm{SR}$ measurements in vitro were 0.58 and $0.89 \mu_{\mathrm{mol} \mathrm{g}}^{-1}$ dry wt $\mathrm{d}^{-1}$, respectively, averaged for all 5 replicates. The replicates had a good reproducibility with relatively low standard deviations $\left(\mathrm{AOM} \pm 0.10 \mu \mathrm{mol} \mathrm{g}^{-1}\right.$ dry $\mathrm{wt} \mathrm{d}^{-1}, \mathrm{SR} \pm 0.08$ $\mu \mathrm{mol} \mathrm{g}{ }^{-1}$ dry wt $\mathrm{d}^{-1}$ ). SR rates were similar in comparison to those measured in long-term incubations at the respective methane concentration (about $0.5 \mu \mathrm{mol}$ $\mathrm{g}^{-1}$ dry wt $\mathrm{d}^{-1}$, Nauhaus et al. 2002). The ratio of AOM to SR was $0.7: 1$ in the present short-term radiotracer incubations compared to a ratio of 0.9:1 in long-term incubations. The ratio between $\mathrm{AOM}$ and SR indicates a close coupling between the 2 processes when compared with nonseep locations where SR is fueled by degradation of organic matter where SR rates exceed AOM rates by a factor of 10 (Hinrichs \& Boetius 2002). 


\section{DISCUSSION}

\section{The coupling of AOM and SR}

\section{Beggiatoa and Calyptogena fields}

A comparison of $\mathrm{AOM}$ and $\mathrm{SR}$ rates indicates that SR is fueled mainly by methane at fluid impacted sites of $H R$, as also suggested by Boetius et al. (2000b). However, the ratio between the 2 processes differed: SR appeared to be 80 to $90 \%$ methane-dependent at the Calyptogena field. At the Beggiatoa field 1, average SR was 6-fold higher than average AOM. However, the peak of SR fell close to the peak of AOM biomass. A first conclusion would be that the sulfate-reducing bacteria of the AOM consortium at Beggiatoa field 1 may have used carbon sources other than methane to some extent. However, in vitro experiments with slurries from HR sediments demonstrated that methaneindependent SR is low compared to slurries amended with methane (Nauhaus et al. 2002). Additional carbon sources such as the decaying parts of the Beggiatoa mat or higher hydrocarbons can be ruled out as an explanation for discrepancies between AOM and SR. The growth rate of the Beggiatoa community (5.0 mmol C m $\mathrm{m}^{-2} \mathrm{~d}^{-1}$, Sommer et al. 2002), which should approximately balance decay, is only half of the maximum carbon input of deposited organic matter in this region (9.2 mmol C m $\mathrm{m}^{-2} \mathrm{~d}^{-1}$, Sommer et al. 2002). The presence of ethane, propane and butane was confirmed within the uppermost $10 \mathrm{~m}$ of the southern summit during cruise 204 of the Ocean Drilling Program (Trehu et al. in press), but concentrations did not even reach $1 \%$ of methane $\left(\mathrm{C}_{1}: \mathrm{C}_{2 \text { to } 4} \geq 1000\right)$. Therefore we hypothesize that the discrepancies between AOM an SR were attributed to both methodical problems, caused by methane losses during decompression and incubation, and the heterogeneity of the sediment. It has to be kept in mind that AOM and SR were measured in different cores. The system at the high fluid-impacted fields might be so variable that samples taken only centimeters apart from each other show such high variations. This heterogeneity could be caused by transient gas injections from the lower reservoir or by changes in pathways of fluids and gases. Authigenic carbonates that precipitate in surface sediments at $H R$ as a product of AOM could redirect or inhibit rising gasses and fluids (Bohrmann et al. 1998). The close coupling between potential AOM and SR rates that was observed in the homogenized sediment confirms this assumption. A scheme illustrating the causes of heterogeneity at HR is shown in Fig. 4.

\section{Acharax field}

There is not enough methane supply to fuel a dense AOM community in the surface sediments of Acharax fields, which are located adjacent to the Calyptogena fields at HR seeps. Here, methane fluxes are significantly lower compared to other HR provinces and sulfide does not appear until $15 \mathrm{~cm}$ sediment depth (Sahling et al. 2002). Upward diffusing methane is most likely oxidized aerobically within the oxygenated surface sediment. Aerobic methane oxidation is also measured by the ${ }^{14} \mathrm{CH}_{4}$ injection method and can not be distinguished from AOM. Methane oxidation was not coupled to SR, but took place close to the sediment surface where oxygen was available. In contrast, SR was highest towards the bottom of the sediment cores. The SR rates are in the same order of magnitude compared to slope sediments (620 m water depth) off the Washington coast $\left(0.66 \mathrm{mmol} \mathrm{m} \mathrm{m}^{-2} \mathrm{~d}^{-1}\right.$, integrated over 0 to $30 \mathrm{~cm}$ sediment depth, Kristensen et al. 1999) and are therefore presumably not influenced by methane venting. Thus, SR seems to be solely fueled by organic matter deposited from the water column.

\section{The role of sulfate}

At the Beggiatoa field 1 and the Calyptogena field, SR decreased to low rates when sulfate dropped to concentrations around $2 \mathrm{mM}$. Below this zone, no further sulfate depletion was observed down to $10 \mathrm{~cm}$ sediment depth. At Beggiatoa field 2, sulfate concentration also did not decrease below $2 \mathrm{mM}$. It is unclear why sulfate is not depleted to zero as long as methane is available. A similar threshold value was observed in

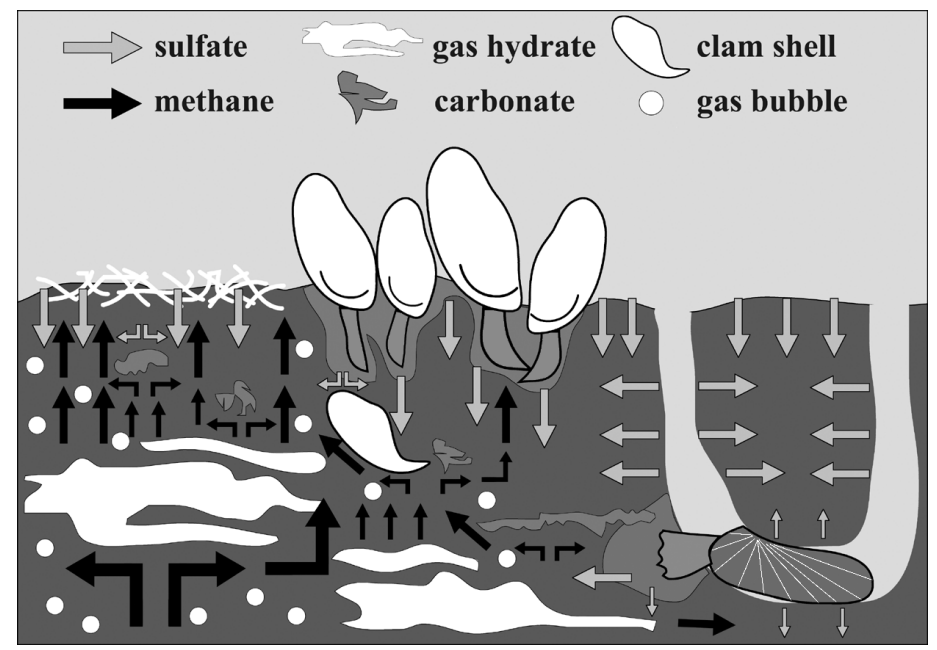

Fig. 4. Scheme illustrating heterogeneity of surface sediments at HR causing high deviations in AOM and SR replicates 
subsurface sediments of another gas hydrate location in the Gulf of Mexico (S. Joye pers. comm.). Low sulfate concentrations accompanied by high sulfide concentrations, reaching values up to $26 \mathrm{mM}$ below the sediment surface (Sahling et al. 2002), might make AOM thermodynamically unfavorable. It is possible that sulfide was toxic at these levels. For both Beggiatoa fields the drop in sulfate concentration was also accompanied with a decrease in aggregate numbers, again showing the coupling of AOM, SR and the biomass of the methanotrophic community.

\section{Spatial and temporal variability of AOM}

AOM rates at HR are among the highest ever measured in marine sediments (compare with Hinrichs \& Boetius 2002 and references therein). Typically, marine sites with high rates of AOM are permanently supplied with large amounts of methane seeping from deep reservoirs. A special situation appears when methane seepage occurs within the gas hydrate stability zone, causing the formation of methane hydrates. Methane hydrates represent a temporary storage of methane (Kvenvolden 1993). At the stability limit, dissociating hydrates provide a steady flow of methane into the AOM zone replenishing the methane that has been consumed by the AOM consortium. When methane concentration surpasses saturation, free gas escapes as rising gas bubbles which bypass the AOM zone (Luff \& Wallmann 2003). At HR, where methane hydrates form within the upper meter of the seafloor, $\mathrm{AOM}$ can be expected to reach high rates due to a steady supply of methane from below and input of sulfate from above.

\section{Beggiatoa fields}

Except for gas vents, Beggiatoa fields at HR are the provinces with the highest methane fluxes as well as the largest variation in fluxes (Torres et al. 2002, Tryon et al. 2002). Thus, maximum rates and a high patchiness of AOM were expected and observed. Beggiatoa field 2 revealed the highest AOM rates of all investigated sites. The peak rate agreed with estimates of Boetius et al. (2000b), who predicted a maximum AOM rate of about $5 \mu \mathrm{mol} \mathrm{cm} \mathrm{cm}^{-3} \mathrm{~d}^{-1}$ at HR from SR measurements. But the comparably low rates found in Beggiatoa field 1 indicate that AOM may vary over an order of magnitude in this province. Variation in methane concentration were most likely responsible for differences in $\mathrm{AOM}$, as both fields contained about the same amount of AOM consortia and showed similar sulfate profiles. High variation of AOM between replicates of the same deployment again signify that heterogeneity occurs even within small dimensions (i.e. $<1 \mathrm{~m}^{2}$; see also Fig. 4).

Based on methane effluxes between 10 and $100 \mathrm{mmol}$ $\mathrm{m}^{-2} \mathrm{~d}^{-1}$ from the Beggiatoa fields into the overlying water column (Torres et al. 2002) and an AOM rate of about $100 \mathrm{mmol} \mathrm{m}^{-2} \mathrm{~d}^{-1}$ (this study), we assume that the microbial filter is able to consume between 50 and $90 \%$ of the methane that is advectively transported through the surface sediments of Beggiatoa fields. Unpredictable variations of methane fluxes due to transient gas injection might account for releases of methane into the overlying water.

Peak rates of AOM located immediately below the Beggiatoa mat (1 to $2 \mathrm{~cm}$ ) as predicted from former investigations on SR rates (Boetius et al. 2000b), flux modeling (Luff \& Wallmann 2003) and FDA (determination of exoenzymatic hydrolytic activity using fluorescein-di-acetate as substrate; Sommer et al. 2002), were not found in this study. In contrast, AOM rates in both Beggiatoa fields were low close to the sediment surface, with maxima always located below $2 \mathrm{~cm}$ depth.

\section{Calyptogena field}

Maximum SR and a rapid decline in sulfate concentration occurred below $3 \mathrm{~cm}$ sediment depth. We expected that the digging and pumping activity of the clams would affect the upper 3 to $4 \mathrm{~cm}$ of the sediment by irrigating the sediment with oxygenated seawater (Sahling et al. 2002). The energy supply of Calyptogena is based on sulfide-oxidizing bacteria, which is harbored in the gills of the clams (Fisher 1990). The clams dig their feet into the reduced sediments to take up sulfide. Sulfide is transported to the gills via sulfidebinding compounds in the clam blood where it is oxidized by the symbionts. We hypothesize that the digging and pumping activity of the clams enriches the upper sediment with oxidizing agents (e.g. $\mathrm{O}_{2}, \mathrm{NO}_{3}{ }^{-}$) that may be toxic for the AOM consortium and therefore shift SR below the penetration depth of the clams' feet. The pumping activity of the clams is expected to enrich the sediment also with sulfate and thus to stimulate SR after the depletion of prior oxidizing agents. The maximum AOM was also located below the depth of foot penetration but reached appreciable rates above that depth as well. It has to be taken into account that the uppermost rates represented aerobic oxidation of methane as they exceeded SR. The presence of aerobic methanotrophs in surface sediments of the Calyptogena fields has been confirmed in laboratory studies (A. Eppelin \& M. Krueger unpubl. data). 
Methane effluxes into the overlying water column from Calyptogena fields are reported to be of a 1 to 2 order of magnitude lower than Beggiatoa fields (between 0 and $1 \mathrm{mmol} \mathrm{m}^{-2} \mathrm{~d}^{-1}$, Torres et al. 2002). Considering that AOM rates were about $56 \mathrm{mmol} \mathrm{m}^{-2} \mathrm{~d}^{-1}$ at the Calyptogena field, this would result in a consumption of 99.8 to $100 \%$ of the upward diffusing methane. Within this province, constant methane fluxes and a steady sulfate supply due to the pumping activity of the clam provide stable conditions for the AOM consortium. Methane is therefore removed efficiently before it reaches the overlying water. Deviations of AOM in replicates of the same deployment could be due to clam activity, uneven distribution of gas hydrates or the presence of carbonates (see also Fig. 4).

It has to be mentioned at this point that although highest methane turnover was found at Beggiatoa field 2, the integrated AOM rates within the Calyptogena field are nearly as high as the average depthintegrated $\mathrm{AOM}$ rates of the 2 Beggiatoa fields. We assume that AOM at the Beggiatoa fields is highest, but most variable due to fluctuating gas discharges. Gas discharge from greater depths thus represents a temporally variable methane supply in addition to methane supply from dissociating gas hydrates. In contrast, AOM at the Calyptogena fields should be relatively stable due to a permanent methane supply from dissociating gas hydrates. Further investigations of the different provinces are needed to confirm this assumption.

\section{Acharax field}

The methane oxidation in the uppermost layers of the Acharax field most likely represents aerobic processes. A correlation between AOM and SR in deeper parts of the sediment is tenuously based on molecular evidence. Whereas almost no aggregates are present in the assumed aerobic zone, small amounts were found within the zone of increasing SR (below $4 \mathrm{~cm}$ ). However, signals of AOM specific lipid fatty acids, related to Desulfosarcina/Desulfococus (M. Elvert et al. unpubl.), are very weak at this province compared to active vent sites and the $\delta^{13} \mathrm{C}$ values are not characteristic for AOM
(M. Elvert pers. comm.). Considerable AOM derived biomass is either shifted to deeper parts of the sediment or the aggregates in the SR zone represent relicts of former venting. Acharax fields sometimes include Calyptogena shells in deeper sediment layers, and Acharax shells were found in both Calyptogena- and Beggiatoa fields (T. Treude pers. obs.). This may suggest that the horizontal distribution of methane-seepage at HR surfaces is most likely changing over time.

\section{Numerical transport-reaction model}

The transport-reaction model was applied to calculate AOM rates in surface vent sediments covered with Beggiatoa mats. The model input includes measured porosity data and the average depth distribution and density of aggregates of the AOM consortium observed in surface sediments from Beggiatoa fields (Fig. 3a,b). The extent and location of the modeled AOM is principally affected by upward fluid flow. It was, however, not possible to measure fluid flow into the surface sediments in situ. Instead, the rate of upward fluid flow was estimated by fitting the dissolved sulfate profile to the measured concentration data. The resulting flow velocities ( 0 to $10 \mathrm{~cm} \mathrm{yr}^{-1}$; Table 4 ) fall into the range of flow rates previously determined by modeling of sulfate profiles (Luff \& Wallmann 2003) and are the low end of fluid flow measured in situ at Beggiatoa fields (Tryon et al. 2002). In the model, SR occurs only via AOM so that SR and AOM rates always have the same values. This approximation is appropriate for reasons mentioned above.

The AOM rates derived from the model fall into the lower range of values determined by radiotracer measurements (rates between 13.3 and $15.4 \mathrm{mmol} \mathrm{m}^{-2} \mathrm{~d}^{-1}$ in the model [Table 4] compared to rates between 5.1 and $99 \mathrm{mmol} \mathrm{m} \mathrm{m}^{-2} \mathrm{~d}^{-1}$ in radiotracer measurements [Table 3]). For Beggiatoa field 1, the depth distribution of AOM and SR derived from radiotracer measurements and modeling both revealed subsurface maxima at 4 to $6 \mathrm{~cm}$ sediment depth (Fig. 5). Here, rising methane and sulfate diffusing into the sediment from the overlying bottom water meet, allowing AOM and SR to proceed at maximum velocity. Measured AOM

Table 4. Model results. Porosity at zero depth $\left(P_{0}\right)$, porosity at infinite depth $\left(P_{F}\right)$, attenuation coefficient defining the decrease in porosity with depth $(P)$, upward fluid-flow rate $\left(V_{I}\right)$, depth integrated AOM rate, and flux of methane into the overlying bacterial mat and overlying water

\begin{tabular}{|lcccccc|}
\hline Field & $P_{0}$ & $P_{F}$ & $\begin{array}{c}P \\
\left(\mathrm{~cm}^{-1}\right)\end{array}$ & $\begin{array}{c}V_{I} \\
\left(\mathrm{~cm} \mathrm{yr}^{-1}\right)\end{array}$ & $\begin{array}{c}\mathrm{AOM} \\
\left(\mathrm{mmol} \mathrm{m}^{-2} \mathrm{~d}^{-1}\right)\end{array}$ & $\begin{array}{c}\text { Benthic CH } \\
\left(\mathrm{mmol} \mathrm{m}^{-2} \mathrm{~d}^{-1}\right)\end{array}$ \\
\hline Beggiatoa field (1) & 0.75 & 0.60 & 0.1 & 0 & 13.3 & 0.6 \\
Beggiatoa field (2) & 0.65 & 0.65 & 0 & 10 & 15.4 & 4.0 \\
\hline
\end{tabular}



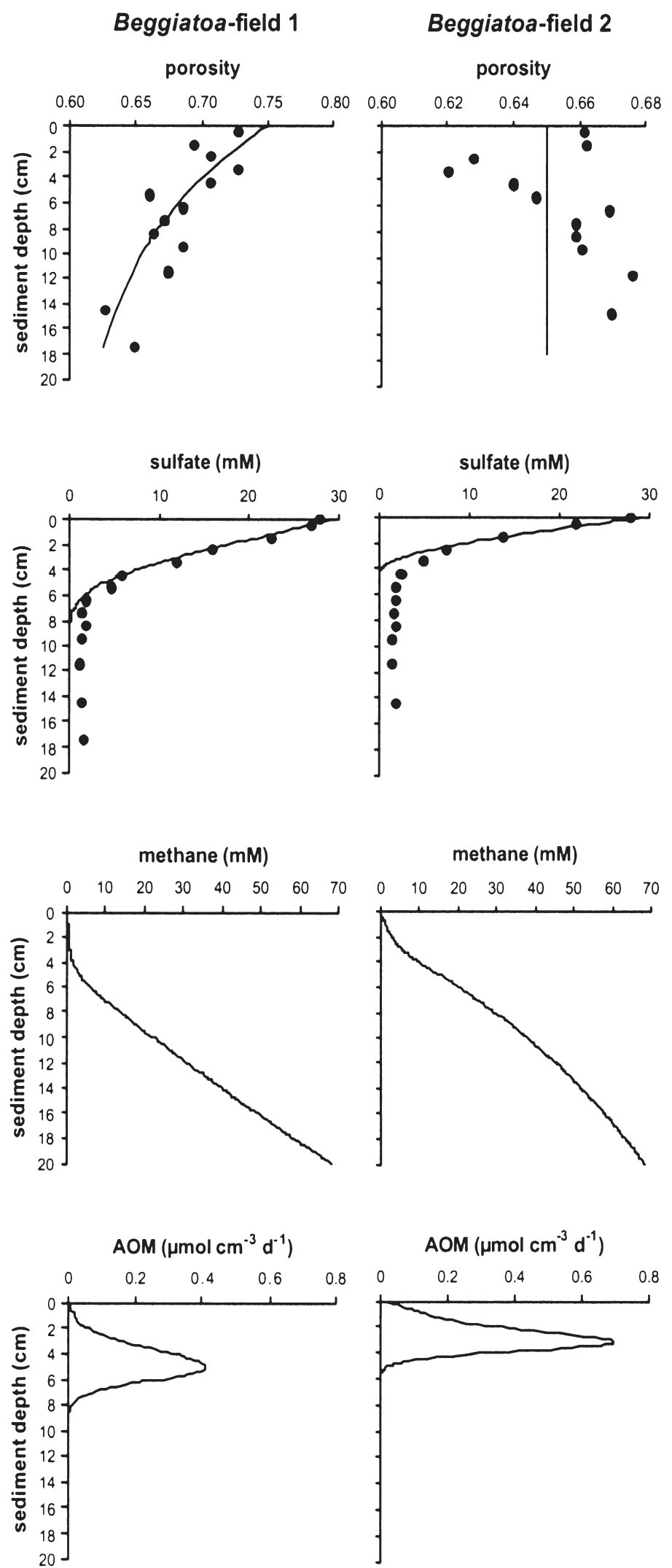

Fig. 5. Sediment data and model results. (๑) indicates measured data while (-) gives the results of the transport-reaction model rates in Beggiatoa field 1 show the same magnitude as modeled rates, whereas measured SR rates revealed maxima up to 1 order of magnitude higher than predicted from the modeled AOM rates. Modeled AOM rates of Beggiatoa field 2 are 1 order of magnitude lower compared to measured rates.

The model shows that the major portion (between 79 and $96 \%$ ) of methane transported to the surface as dissolved gas in rising vent fluids is oxidized anaerobically within the surface sediment (Table 4). The efficiency of methane oxidation depends on the rate of upward fluid flow so that a significant methane fraction can only be expelled into the bottom water at flow velocities $>100 \mathrm{~cm} \mathrm{yr}^{-1}$ (Luff \& Wallmann 2003).

\section{Comparison of rate measurement and rate modeling}

In the 1-dimensional model approach used in this paper, it was assumed that concentration gradients and changes in reaction rates occur only with sediment depth. The radiotracer measurements revealed a strong lateral heterogeneity which was not anticipated and considered in the model. Thus, it is necessary to develop multi-dimensional models which allow for strong variability in all spatial dimensions to better simulate the complex processes in hydrate-bearing surface sediments. Radiotracer measurements, on the other hand, are not able to mirror exact in situ processes due to degassing of methane upon retrieval, leading to lowered methane concentrations and disturbances in the cores. However, at Beggiatoa fields, both tools came up with similar amounts of depth integrated AOM and its vertical distribution, although concerning different input parameters. It is therefore desirable to combine both tools in future studies in order to understand other highly dynamic systems above gas hydrates.

\section{CONCLUSION}

At $\mathrm{HR}$, microbial $\mathrm{AOM}$ is an efficient filter for methane preventing its emission from the surface sediments to the hydrosphere as confirmed by modeling and measuring methane turnover. In the surface sediments $(<10 \mathrm{~cm})$ of Beggiatoa fields, between 50 and $90 \%$ of the rising methane is oxidized despite high flow rates, while in Calyptogena fields, nearly $100 \%$ is oxidized. Measured AOM rates of about $100 \mathrm{mmol} \mathrm{m}^{-2}$ $\mathrm{d}^{-1}$ are among the highest ever found in methanebearing sediments of the marine environment. SR is mostly fueled by methane at fluid impacted sites but exceeds AOM in some cases, most likely due to sediment heterogeneity. AOM is highest at Beggiatoa 
fields, where highest fluid flow and methane fluxes occur, followed by Calyptogena fields. At Acharax fields, methane fluxes are low and limit AOM. Measured AOM and SR rates reveal a high degree of patchiness at both the Beggiatoa and Calyptogena fields. Fluctuating gas discharges, differences in fluid flow, uneven distribution of gas hydrates and differences in macrofaunal activity may all contribute to this patchiness.

Acknowledgements. We thank the officers, crew and shipboard scientific party of the RV 'Sonne' for the excellent support during expedition SO-148/1. We particularly thank D. Rickert for providing sulfate and porosity data as well as $\mathrm{T}$. Lösekann, H. Löbner and M. Hartmann for their technical assistance. The manuscript benefited from very helpful comments of K. Nauhaus, B. Orcutt, T. Ferdelman, and 3 anonymous reviewers. This study was made possible by the programs TECFLUX II (Tectonically induced Fluxes, grant 03G0148A), MUMM (Mikrobielle Umsatzraten von Methan in gashydrathaltigen Sedimenten, grant 03G0554A), LOTUS (Long-term observatory for the study of control mechanisms for the formation and destabilization of gas hydrate, grant 03G0565A) and OMEGA (Oberflächennahe Marine gas hydrate, grant 03G0566A) supported by the Bundesministerium für Bildung und Forschung (BMBF, Germany). Further support was from the Max-Planck-Gesellschaft (MPG, Germany). This is publication GEOTECH-20 of the GEOTECHNOLOGIEN program of the BMBF and the Deutsche Forschungsgesellschaft (DFG, Germany).

\section{LITERATURE CITED}

Berner RA (1980) Early diagenesis: a theoretical approach. Princeton University Press, Princeton, New Jersey

Boetius A, Lochte K (1996) Effect of organic enrichments on hydrolytic potentials and growth of bacteria in deep-sea sediments. Mar Ecol Prog Ser 140:239-250

Boetius A, Ferdelman T, Lochte K (2000a) Bacterial activity in sediments of the deep Arabian Sea in relation to vertical flux. Deep-Sea Res II 47:2835-2875

Boetius A, Ravenschlag K, Schubert CJ, Rickert D and 6 others (2000b) A marine microbial consortium apparently mediating anaerobic oxidation of methane. Nature 407: 623-626

Bohrmann G, Greinert J, Suess E, Torres M (1998) Authigenic carbonates from the Cascadia subduction zone and their relation to gas hydrate stability. Geology 26(7):647-650

Boudreau BP (1996) A method-of-lines code for carbon and nutrient diagenesis in aquatic sediments. Comput Geosci 22(5):479-496

Boudreau BP (1997) Diagenetic models and their implementation. Springer-Verlag, Berlin

Elvert M, Boetius A, Knittel K, Jørgensen BB (2003) Characterization of specific membrane fatty acids as chemotaxonomic markers for sulfate-reducing bacteria involved in anaerobic oxidation of methane. Geomicrobiology 20: 403-419

Elvert M, Greinert J, Suess E, Whiticar MJ (2001) Carbon isotopes of biomarkers derived from methane-oxidizing microbes at Hydrate Ridge, Cascadia Convergent Margin. Geophysical Monograph 124, American Geophysical Union, Washington, DC, p 115-129
Fisher CR (1990) Chemoautotrophic and methanotrophic symbiosis in marine invertebrates. Rev Aquat Sci 2:399-436

Fossing H, Jørgensen BB (1989) Measurements of bacterial sulphate reduction in sediments: evaluation of a singlestep chromium reduction method. Biogeochemistry 8: 205-222

Gutt C, Asmussen B, Press W, Merkl C and 5 others (1999) Quantum rotations in natural methane-clathrates from the Pacific sea-floor. Europhys Lett 48(3):269-275

Hinrichs KU, Boetius A (2002) The anaerobic oxidation of methane: new insights in microbial ecology and biogeochemistry. In: G. Wefer, D. Billett, D. Hebbeln et al. (eds) Ocean Margin Systems. Springer-Verlag, Berlin, p 457-477

Iversen N, Blackburn TH (1981) Seasonal rates of methane oxidation in anoxic marine sediments. Appl Environ Microbiol 41(6):1295-1300

Jørgensen BB (1978) A comparison of methods for the quantification of bacterial sulphate reduction in coastal marine sediments. I. Measurements with radiotracer techniques. Geomicrobiol J 1(1):11-27

Knittel K, Boetius A, Lemke A, Eilers H, Lochte K, Pfannkuche O, Linke P, Amann R (2003) Activity, distribution, and diversity of sulfate reducers and other bacteria above gas hydrate (Cascadia Margin, OR). Geomicrobiol J 20: 269-294

Kristensen E, Devol AH, Hartnett HE (1999) Organic matter diagenesis in sediments on the continental shelf and slope of the eastern tropical and temperate North Pacific. Cont Shelf Res 19:1331-1351

Kvenvolden K (1993) A primer on gas hydrates. US Geol Surv, No. 1570 , p 279-291

Luff R, Wallmann K (2003) Fluid flow, methane fluxes, carbonate precipitation and biogeochemical turnover in gas hydrate-bearing sediments at Hydrate Ridge, Cascadia Margin: numerical modeling and mass balances. Geochim Cosmochim Acta 67 (18):3403-3421

Luff R, Wallmann K, Grandel S, Schlüter M (2000) Numerical modelling of benthic processes in the deep Arabian Sea. Deep-Sea Res II 47(14):3039-3072

Meyer-Reil LA (1983) Benthic response to sedimentation events during autumn to spring at shallow water station in the western Kiel Bight. Mar Biol 77:247-256

Nauhaus K, Boetius A, Krüger M, Widdel F (2002) In vitro demonstration of anaerobic oxidation of methane coupled to sulphate reduction in sediment from marine gas hydrate area. Environ Microbiol 4(5):298-305

Sahling H, Rickert D, Raymond WL, Linke P, Suess E (2002) Macrofaunal community structure and sulfide flux at gas hydrate deposits from the Cascadia convergent margin, NE Pacific. Mar Ecol Prog Ser 231:121-138

Sommer S, Pfannkuche O, Rickert D, Kähler A (2002) Ecological implications on surficial marine gas hydrates for the associated small-sized benthic biota at the Hydrate Ridge (Cascadia Convergent Margin, NE Pacific). Mar Ecol Prog Ser 243:25-38

Suess E, Torres ME, Bohrmann G, Collier RW and 7 others (1999) Gas hydrate destabilization: enhanced dewatering, benthic material turnover and large methane plumes at the Cascadia convergent margin. Earth Planet Sci Lett 170:1-15

Torres ME, McManus J, Hammond D, Angelis de MA and 5 others (2002) Fluid and chemical fluxes in and out of sediments hosting methane hydrate deposits on Hydrate Ridge, OR. I. Hydrological provinces. Earth Planet Sci Lett 201:525-540

Trehu A, Bohrmann G, Rack F and 47 others (in press). Drilling gas hydrate on Hydrate Ridge, Cascadia Conti- 
nental Margin. Ocean Drilling Program, Leg 204 (preliminary report), Texas A \& M University, College Station, TX Tryon MD, Brown KM, Torres ME (2002) Fluid and chemical flux in and out of sediments hosting methane hydrate deposits on Hydrate Ridge, OR. II. Hydrological processes. Earth Planet Sci Lett 201:541-557

Wallmann $\mathrm{K}$, Linke $\mathrm{P}$, Suess E, Bohrmann G and 6 others (1997) Quantifying fluid flow, solute mixing, and biogeochemical turnover at cold vents of the eastern Aleutian

Editorial responsibility: Matthias Seaman (Assistant Editor), Oldendorf/Luhe, Germany subduction zone. Geochim Cosmochim Acta 61 (24): 5209-5219

Whiticar MJ, Hovland M, Kastner M, Sample JC (1995) 26. Organic geochemistry of gases, fluids, and hydrates at the Cascadia accretionary margin. Proc Ocean Drilling Program, Sci Res 146(1):385-397

Valentine DL, Reeburgh WS (2000) New perspectives on anaerobic methane oxidation. Environ Microbiol 2(5): $477-484$

Submitted: April 23, 2003; Accepted: September 30, 2003 Proofs received from author(s): December 2, 2003 